\title{
Albania`s Democracy Challenges: External Stimuli and Internal Factors at Play
}

\author{
Ilir Kalemaj Ph.D \\ University of New York Tirana \\ Email: ikalemaj@unyt.edu.al
}

Doi:10.5901/ajis.2016.v5n3p107

\begin{abstract}
The primary question that this paper seeks to explore is: Why Albania did not successfully democratize in the aftermath of Communism although it did not have the nation-building problems that others, from neighboring republics of former Yugoslavia to Baltic countries faced? Intuitive hypotheses would have predicted the Albanian case as a likely case of rapid democratization, given its ethnically homogeneous population of the youngest age in Europe, coming out of the most isolated communist regime with strong totalitarian tendencies. Quite the opposite, not only Albania is facing an uphill battle to democratize to the date, but the quality of political representation has worsened and currently the main debate evokes the question of decriminalization of political elite. In the eve of the 25th anniversary of regime change in Albania, this question seeks additional attention to explore the barriers Albania faced and why they have persisted for so long? In the present study I undertake a critical approach of political antagonism and I argue that the increasing authoritarian tendencies and lack of institutional bedrock as the primary factors that can explain the Albanian case synchronically from 1992 to present day. I particularly focus at certain critical junctures which I deem to have had more impact in Albania's lack of progress. To investigate the course of events in the two countries I use both discourse and content analyses. Through process tracing I investigate particular critical juncture that I render to be more significant than others to explain shifts in Albania's democratization process and analyze why the transition has been a challenge. The structure consists in a short overview of democratization process in Eastern Europe, then it focuses on Albania's transition, before it continues with an emhpasizes of external constraints. It further follows with a discussion of domestic challenges before it concludes with a summary of findings.
\end{abstract}

Keywords: Transition, democratization, Albania, authoritarian tendencies, political antagonism

\section{Introduction}

Albania has had an uphill road in its democratizing process, although puzzling enough Albania had consistently shown a general indifference toward the myriad of problems that were occurring in nearby (former) Yugoslavia in the early 1990s. This can be explained by Albania`s ethnic homogeneity, a period of ultimate isolation especially during the last decade and half of communism that combined with lack of infrastructure, lack of resources and general poverty, led Albanians to massively flee the country in the aftermath of fall of the totalitarian regime. So, the desire of the majority of people was to leave the country, rather than fight to expand it through irredentist wars, which means evoking any nationalist claims visà-vis Albanian-speaking territories in former Yugoslavia etc. This was the major reason, coupled with reasonably high foreign pressures that constrained Albanian politicians not to take any step in the dangerous road of irredentist claims, which could threaten the volatile Western Balkans to go even faster downhill. Furthermore, Albania had signed a trade and cooperation agreement with European Union in the 1992, when Albania as a result became eligible for PHARE funding - under external relations aid scheme. Albania also underwent the shock therapy, which consisted on rapid privatization and structural reforms that elsewhere (i.e. Czech Republic, Estonia) proved to be highly successful. Thus, to paraphrase Clauss Offe, Albania did not face triple challenges that required inter alia national identity-building and stateformation, but still faced the rockiest road to democratization, even compared to regional standards.

The primary question that this paper seeks to explore is: Why Albania did not successfully democratize in the aftermath of Communism although it did not have the nation-building problems that others, from neighboring republics of former Yugoslavia to Baltic countries faced? Intuitive hypotheses would have predicted the Albanian case as a likely case of rapid democratization, given its ethnically homogeneous population of the youngest age in Europe, coming out of the most isolated communist regime with strong totalitarian tendencies. The matter of fact is that Albania faced a rocky road of transition which for some authors has not yet been finished (Krasniqi, 2008; Kalemaj, 2014). Here I argue that bitter political fights, changes in electoral system and consequent contestation following each set of elections and lack of institutionalism remain the primary factors that can explain the Albanian case from 1992 to present day. 


\section{Literature Review}

\subsection{The Democratization Process in Eastern Europe}

In the period after the fall of Iron Curtain that had imposed an ideological unified dogma in Eastern Europe, new legacies quickly started to fill the vacuum. One of the first phantoms most of these countries had to face in their triple transition toward democracy, market economy and state-building (Offe, 1991, p. 873) was the question of a new identity. An identity strongly connected to their nation-state, which sometimes brought to an end long decades of successful federations, such as the Soviet Union, Czechoslovakia and Yugoslavia. Many newly established states found themselves to have little proportional numerical supremacy in the new state. This had ample consequences for everyday politics because it brought into existence the old forgotten phantom of ethnic markers which was especially problematic in the relations that newly nationalizing states created with minorities.

In the present scholarship about the former Eastern European countries, we have seen two main currents of democratization processes, once that speaks about a successful route toward consolidation of democratic regimes and takes as its benchmark the Vishegrad and Baltic countries (Schimmelfennig, 2007), and one that testifies for the opposite, an often protracted transition with a myriad of problems as it pertains the (lack of) rule of law and state corruption as the case of Western Balkans testifies, although there are many shades within (Rupnik, 2000). Moreover, even among the Balkan countries, there are idiosyncrasies of the transition processes, with various degrees of success regarding their democratization paths. For example Albania has been sometimes treated as a "most difficult case of democratisation or usually treated as an outlier compared to other post-communist experiences of regime change" (Elbasani 2008, p. 125). I tend to believe and I further argue below that Albania's difficulty with democratization relies especially in an absurd and contingent political antagonism that has not been either based on principles, neither in ideology. The roots of the problem is antagonism fuelled by ad hominem attacks in order to fill the ideological vacuum, to keep the attention away from major economic and infrastructure problems and inability of the political class to offer long lasting solutions.

\section{Research Methods}

I particularly focus at certain critical junctures which I deem to have had more impact in Albania`s lack of progress. To investigate the course of events in the two countries I use both discourse and content analyses. Through process tracing I investigate particular critical juncture that I render to be more significant than others to explain shifts in Albania`s democratization process and analyze why the transition has been a challenge. The structure consists in a short overview of democratization process in Eastern Europe, then it focuses on Albania's transition, before it continues with an emhpasizes of external constraints. It further follows with a discussion of domestic challenges before it concludes with a summary of findings.

\section{Analysis Result}

\subsection{The Rocky Road to Albania's Transition}

The data reveals that in 1992 in Albania, with the start of democratic transition and power shifts from the autocracy of communists to a multi-party system, a new opportunity for expanding nationalist propaganda opened up. It was expecially telling that "the Democratic Party leadership used an ethnically inclusive rhetoric that was addressed to Albanians inside and outside state borders with promises for its revindication and more active role-play of the 'homeland' to the affairs of ethnic kin, as well as allowing diaspora to actively take part in domestic politics" (Kalemaj, 2014: 188). After coming to power however, the discourse was suddenly 'normalized' with nation and state mapping onto each other in political and cultural discourse, where dissent nationalist voices that visualized a pan-Albanian federation were marginalized. This mostly happened because of rising international actors' pressures that could not tolerate such discourse in the eve of ethnic conflict ruptures in nearby rump Yugoslavia. (Kalemaj, 2014, p.188).

In 1997 to 1999, after the Socialist Party had come to power following an abrupt popular revolt and when Kosovar crises erupted with many fleeing to Albania to escape ethnic cleansing, we witness an important critical juncture. It was in this period that connections between the "cosmopolitan" socialists and Kosovo's armed guerrila body KLA formed a strange but useful combination that secured military training and other logistical support in and out of Albania to Liberation fighters, much needed at the period. However, this period was more an effort to return the missing state back 
and to recreate the institutions that were shattered by the civil conflict of 1997, rather than an effort to secure democratic standarts. Prime Minister Nano is credited to share power with a number of former prominent leaders from the Right, such as Sabri Godo and Arben Imami who were in charge of leading the process of drafting the constitution while others became ministers, such as Pollo, Zogaj, Rama and Ngjela. Also of symbolic importance was the incorporation of civil society and media members that were given important positions such as Ardian Klosi, Fatos Lubonja, Frrok Cupi etc. But these were seen as efforts to secure a relatively comfortable governance, without the common nuissance from the opposition, rather than credible efforts of democratization and addresing legitimacy questions. Democracy standarts continued to suffer and as result the political crises became acute. The temporary détente between the Socialists and Democrats in 2002, following the consensual election of President Moisiu, was only a fleeting example of success that resembled just a glimpse of hope, amidst the overall scepticism that surrounded both camps. As a result of such degree of misbelief between the two parties and respective political leaders, Albania continued to have an antagonistic political scence, where the opponent was demonized and considered an enemy, rather than simply a political adversary with whom pacts were possible.

\subsection{External Constraints to Albanian Transition: Stopping Nationalism and Encouraging Stability}

Notwithstanding the electoral rhetoric, President Berisha was to backpedal soon from the electoral stated goals, immediately after he took power in 1992, because he came to realize "the responsibilities of the office, which dictated the need to abide by the norms of international law to which the Albanian state was a party." (Kola, 2003, p. 223). Evidence of backpedaling can be seen when Berisha scaled down around the years 1993-94 the nationalist rhetoric, to accept talking of Kosovo problem as a 'basic human right' for rump Yugoslavia in international forums rather as framed in nationalist framework that he used up to then (Kola, 2003, p.223). ${ }^{1}$ And as he frankly admitted much later, in another example of his ambiguous stance toward Kosovar Albanians: "[i]n every kind of circumstance, the Kosovo question has not been a problem between Albania and Serbia and I have never accepted it to be a problem of these two countries. This is a problem of international community, of the citizens and Kosovar political leadership and of course Serbia who has taken an active part in it. ${ }^{2}$

Such ambivalent positions in the first half of 1990s were clearly dictated by the international pressures that were growing in the advent of Yugoslav conflict and dismemberment of the Federation there. An Ethnic [Greater] Albania that would rival Milosević's "Greater Serbia" as well as "Greater Croatia" projects was not what the Contact Group, EU, NATO or other international actors wanted. Later, after Dayton settlement, when Serbs turned the attention toward Kosovo and started to ethnically cleanse the province there, the mood of the majority of international community was increasingly influenced by atrocities shown by global media and having in mind previous scenarios of Ruanda and B-H. Some leaders, such as Tony Blair directly advocated a military conflict resolution and were successful in also convincing U.S. President and majority of EU countries (Blair, 2011). When direct external intervention combined with a seemingly elite pact in Albania proper to work toward a unified agenda on Kosovo, then we have a much more moderate stance of Albanian elite vis-à-vis the Kosovar brethren. Thus, the political rhetoric in Albania and general public discourse shifted into one that fully supported the actions undertaken by leading Western states, as well as their umbrella organizations such as UN, Contact Group, NATO etc.

\footnotetext{
${ }_{1}^{1}$ Being a foreign ministry director and high emissary in some main international organizations (such as CoE and OSCE), Kola has been in a favorable position to witness such shifts and they are minutely tracked in his 2003 book 'the Myth of Greater Albania'. He shows citing documents and other archival materials of the era, how Berisha suddenly switched rhetoric in order to get international support that he really needed after he was defeated in local elections. Thus concessions in foreign policy and 'virtual' map contraction were parallel processes that happened as soon as the international interference started to get noticed and threats perceived.

2 This statement was of August 12, 2008. Two years later, Berisha stated that: "[i]n 1990, in my first public meeting addressed to 100.000 Albanian citizens, I declared to them that our guiding star would be the national question. That was [previously] a taboo. In this context, the opening of Albania, the pluralist era, made possible for the country to change its course into full support for the interests of Albanians in Kosovo." S. Berisha, Interview. 9 dhjetor 2010. Opinion show, KLAN TV. Here, we see his rhetoric becoming suddenly nationalist again, because local elections were going to happen soon and electoral calculations gain the upper hand, while external pressure is not strong enough to prevent the alternative mapping.
} 


\section{Discussion}

\subsection{Albania's Domestic Challenges}

Albanian elections can be taken as an example of democratic deformation and lack of consolidation of good practices, because of their irregularities and mutual contestation that falls into the lines of partisan politics. In turn it enforces the notion of a problematic country that while is on track of joining EU, being a candidate country that waits to open negotiation chapters in the coming months, it still has problems often encountered by new and weak states. The international observers in the country have consistently rated Albanian elections as problematic, partially free or generally regular and free, but with minor problems (Kalemaj, 2008, p.170).

Such were deemed the consecutive elections of 1996, the preliminary elections of 1997 that were held under extreme circumstances and of the 2001. In each of these elections, the opposing political camps strongly contested the results and accused the other camp of interfering with the results, usually and naturally with the losing part raising the voice mostly. In 2001 elections we nonetheless have a new element when in the center of gravity and primary concern became the problem of loopholes that were used by SP and its allies to procure illicit results. Albania at that time had in place the "corrected majoritarian" electoral system with 100 out of 140 deputies elected directly, while the rest would be procured proportionally among the parties and coalitions that passed the minimum threshold. In fact, the coalition mattered more than each single party and the SP, having claimed a marginal victory, urged its sympathizers to vote in the second round for its allies, so that it could maximize the votes for the coalition and secure a steady majority that would allow for stable governance.

In turn, this triggered a swift response from DP that applied the same tactic, otherwise referred as "Dushku" 3 in the 2005 elections and despite the fact that SP chose the very same strategy, tactically DP was superior and more disciplined within and coordinated better with its allies in the coalition to maximize the results.

After strong contestations, this time from SP but also members of civil society and international body, the two major parties DP and SP agreed to amend the electoral code in order to have a fairer distribution of vote throughout the territory while securing higher party discipline within themselves, which were concurrently achieved through the newly agreed electoral code of 2008. That came in expense of the other parties, which strongly contested the unilateral scheme of the two biggest parties.

The new system that resembled that of Spain and was referred as the "Spanish system" to differentiate with the "German" model that was in place before was supposed to increase public participation and improve democratic indicators as well as to improve both gender balance and be more meritocratic in essence. While some of these elements were achieved, like more party discipline, more hybrid zones were created throughout territory and the gender quotas were improved, the overall quality seems in retrospective to have been decreased. The candidates are chosen by party leaders with little regard on how much support those enjoy from party militants and population at large in electoral zones where they run and the electoral lists tend to include more elements with a criminal past that seem to "guarantee" the votes but should not normally be part of the highest legislative body. Recently, due to decriminalization law that was passed with mutual consent and the newly approved Justice reform, attempts are made to 'purify' the Parliament from undesirable elements, present and in the future.

Although OSCE has not been seen as an impartial arbiter of this process from various media, civil society or small political parties, empirical evidence does not directly show this. The OSCE public stances are often politicized and attributed specific political interpretation by different political parties, to remove sensitive issues away from public scrutiny, technocratizing the speech. To conclude, it must be stressed that international actors not only have largely played a significant role in influencing the political processes in Albania but in addition their actions or inactions have been given a one-sided interpretation of 'technocratization' of politics. By this I mean, that some of the hottest topics in Albanian political debate, have been cautiously withdrawn from public sphere and solved in behind-the door situations, away from any public scrutiny and to the detriment of small parties, civil society and ordinary citizens. Furthermore, anytime the prime political actors, especially the government have been criticized in this regard or for failure of certain policies, they had addressed these criticisms by pointing out that they had the support or advice of international institutions in doing so. This has been the most effective mean to silent the adversaries and opponents in a society that still needs to learn how to

${ }^{3}$ Dushku was the name of the region that enabled SP coalition to maximize the number of elected deputes in the second round in 2001 and it loaned its name to the phenomenon in general thereafter. 
walk in its own, without complexes of inferiority that have been continuously persistent in the prolonged transitionary postcommunist period (Kalemaj, 2008, p. 171).

\section{Conclusions}

This paper sought to provide an analytical and critical answer to the puzzle of why Albania did not successfully democratize in the aftermath of Communism although it did not face nation-building and identity challenges like most of the other Eastern European countries. Although Albania seemed to be a likely case of rapid democratization, given its ethnically homogeneous population, a vibrant youth eager to emigrate for better prospects, the country's democratization challenges proved to be arduous in the long run. Albania faced the rockiest road to democratization, even compared to regional standards in the eve of the ethnic wars that led to the dismemberment of Yugoslavia.

Now, in the eve of the $25^{\text {th }}$ anniversary of regime change in Albania, we may safely conclude that political antagonism, the increased authoritarian tendencies and lack of institutional bedrock were the primary factors that can explain the Albanian case synchronically from 1992 to present day. I briefly looked upon different critical junctures which I deem to have had more significant impact in Albania's lack of progress as the main impediments of Albania's democratization process. Albania`s difficulty with democratization lies especially in a continuous political antagonism that has neither principles, nor ideology. The roots of the problem is antagonism that is chiefly manifested in the electoral battles and often camouflaged with a technical debate about the rules of engagements in devising electoral systems as it was argued above, fuelled by ad hominem attacks in order to fill the ideological vacuum, to keep the attention away from major economic and infrastructure problems and inability of the political class to offer long lasting solutions.

\section{References}

Blair, T. (2011). A Journey, Arrow.

Elbasani, A. (2008). "EU Enlargement and State Institutions after Communism - Reforming Public Administration in Albania ", L'Europe en Formation: Revue d'études sur la construction européenne et le fédéralisme / Journal of Studies on European Integration and Federalism.

Kalemaj, I. (2014). Contested Borders: Territorialization of National Identity and Shifts of "Imagined Geographies" in Albania, Peter Lang Ltd Oxford.

Kalemaj, I \& Dorian Jano. (2009). "Authoritarism in the Making? The Role of Political Culture and Institutions in the Albanian Context" CEU Political Science Journal (Peer Reviewed). Joint authored with Dorian Jano. Vol. 4, Issue 2.

Kalemaj, I. (2008). "THE DEPOLITICIZATION OF PUBLIC SPHERE: THE CASE OF ALBANIA". Aktet, Vol. 2. Nr. 2, pp. 169-174.

Kalemaj, I. (2014). Probleme të tranzicionit shqiptar. Botuar te Gazeta Shqiptare dhe Forumi Shqiptar. Accessed 04.10.2015 http://www.forumishqiptar.com/threads/154021-Probleme-t\%C3\%AB-tranzicionit-shqiptar-!

Kola, P. (2003). The Myth of Greater Albania, New York: New York University Press.

Krasniqi, A. (2008). Partitë Politike dhe Sistemet Politike, lliar, Tiranë.

Offe, C. (1991). Capitalism by Design? "Capitalism by Democratic Design? Democratic Theory Facing the Triple Transition in East Central Europe." Social Research: An International Quarterly. Central \& East Europe. Arien Mack, Editor Volume 58, No. 4): 865892.

Schimmelfennig, F. (2007). "European Regional Organizations, Political Conditionality, and Democratic Transformation in Eastern Europe", East European Politics and Societies 21(1), 2007.

J. Rupnik. (2000). "Eastern Europe: the International Context", Journal of Democracy. 11(2).

Berisha, S. (2010). Interview. 9 dhjetor 2010. Opinion show, KLAN TV. 
